SISTEM INFORMASI AKUNTANSI PENJUALAN TUNAI TERKOMPUTERISASI

\author{
VINA ARNITA
}

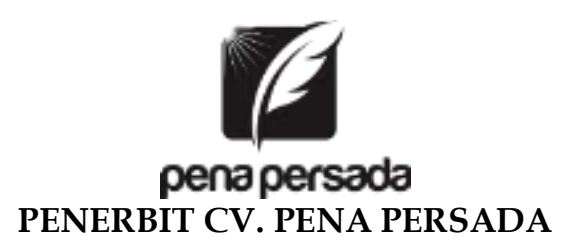




\title{
SISTEM INFORMASI AKUNTANSI PENJUALAN TUNAI TERKOMPUTERISASI
}

\author{
Penulis: \\ Vina Arnita \\ ISBN: \\ Editor: \\ Wiwit Kurniawan \\ Design Cover: \\ Retnani Nur Briliant \\ Layout: \\ Dita Nurul Aviqoh \\ Penerbit CV. Pena Persada \\ Redaksi: \\ Jl. Gerilya No. 292 Purwokerto Selatan, Kab. Banyumas \\ Jawa Tengah \\ Email: penerbit.penapersada@gmail.com \\ Website: penapersada.com Phone : (0281) 7771388 \\ Anggota IKAPI \\ All right reserved \\ Cetakan pertama: 2021
}

Hak Cipta dilindungi oleh undang-undang. Dilarang memperbanyak karya tulis ini dalam bentuk apapun tanpa izin penerbit 


\section{KATA PENGANTAR}

Segala puji dan syukur kepada Tuhan Yesus atas berkat dan rahmat-Nya penulis dapat menyelesaikan skripsi yang berjudul "Sistem Informasi Akuntansi Penjualan Tunai Terkomputerisasi".

CV. Tetap Jaya merupakan perusahaan dagang menengah yang bergerak dibidang penjualan. Adapun masalah yang terjadi pada sistem yang sedang berjalan masih ada menggunakan sistem manual dan menggunakan sistem software kasir Point Of Sale (POS). Dan kurang baiknya sistem pengelolaan persediaan sehingga mengakibatkan kekosongan barang serta adanya perangkapan tugas antar fungsi-fungsi yang ada sehingga kurang efisiensi dan efektivitas dalam kegiatan operasional.

Tujuan kajian dari buku ini adalah untuk mengetahui penerapan sistem informasi Akuntansi (SIA) penjualan tunai terkomputerisasi yang menggunakan software kasir point of sale (POS) pada CV. Tetap Jaya Medan, mengetahui kesesuaian sistem informasi akuntansi (SIA) dengan analisis PIECES, unsur-unsur pengendalian internal dengan literatur. Penelitian ini dilakukan dengan metode kualitatif dengan pendekatan studi kasus dengan data yang diperoleh dari observasi, wawancara, dan dokumentasi. Teknik analisis data yang digunakan adalah analisis deskriptif dan analisis PIECES.

Penerapan sistem informasi akuntansi penjualan tunai terkomputerisasi dengan menggunakan aplikasi point of sale (POS) dapat memudahkan perusahaan atau CV. Tetap Jaya dalam melakukan transaksi penjualan tunai secara cepat, akurat dan up to date. Hasil penelitian ini menunjukkan bahwa CV. Tetap Jaya belum menerapkan sistem informasi akuntansi penjualan tunai tidak sesuai degan teori PIECES dan pengendalian internal menurut teori Mulyadi tahun 2017, disebabkan masih ada transaksi yang masih 
menggunakan sistem manual dan tidak adanya pemisahan tugas dan penggunaan aplikasi point of sale yang kurang maksimal dan adanya kendala saat aplikasi eror tidak ada divisi yang langsung memperbaikinya. Serta tidak adanya pengelolaan sistem persediaan di CV. Tetap Jaya Medan.

Penulis menyadari bahwa buku ini masih banyak kekurangan. Oleh karena itu, saran dan kritik dari pembaca yang Budiman sangat penulis harapkan. Semoga apa yang ada dalam buku ini bisa bermanfaat bagi kemajuan pengetahuan dan memberi keilmuan bagi pembaca sekalian. Terima kasih. 


\section{DAFTAR ISI}

KATA PENGANTAR ........................................................ ii

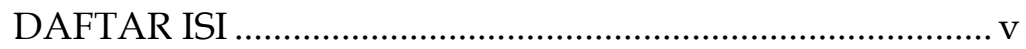

BAB I PENTINGNYA TEKNOLOGI INFORMASI DALAM PERUSAHAAN ................................................................... 1

A. Sistem Informasi dalam Operasional dan Manajerial Perusahaan ............................................................... 1

B. Metodologi Kajian ...................................................... 4

BAB II SISTEM INFORMASI AKUNTANSI ....................... 9

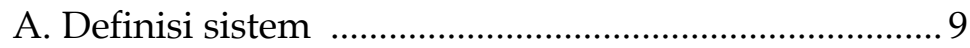

B. Karakteristik Sistem ..................................................... 9

C. Klarifikasi Sistem ....................................................... 11

D. Definisi Informasi ....................................................... 12

E. Definisi Sistem Informasi .......................................... 13

F. Sistem Informasi Akuntansi Penjualan Tunai ........... 14

G. Definisi Akuntansi ........................................................ 15

H. Definisi Sistem Informasi Akuntansi ........................ 16

I. Manfaat Sistem Informasi Akuntansi ........................ 17

J. Tujuan Sistem Informasi Akuntansi ......................... 17

BAB III KONSEP PENJUALAN .......................................... 18

A. Definisi penjualan ....................................................... 18

B. Faktor-Faktor yang mempengaruhi penjualan .......... 18

C. Definisi sistem informasi akuntansi penjualan ......... 19

D. Flowchat Sistem informasi penjualan ......................... 19

E. Prosedur dan fungsi sistem penjualan Tunai ............ 20

F. Unsur pengendalian internal ..................................... 22

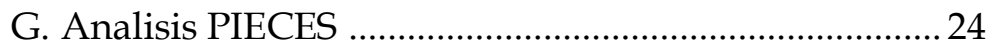

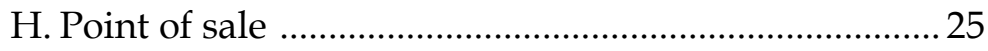


BAB IV PROFIL CV. TETAP JAYA MEDAN .........................26

A. Sejarah singkat CV. Tetap Jaya Medan .......................26

B. Visi dan Misi CV.Tetap Jaya Medan ..........................26

C. Struktur Organisasi CV. Tetap Jaya ..........................27

BAB V PENERAPAN SISTEM INFORMASI AKUNTANSI (SIA) PENJUALAN TERKOMPUTERISASI

A. Sistem informasi akuntansi penjualan tunai yang diterapkan pada CV. Tetap Jaya Medan ...................30

B. Analisis sistem penjualan ..........................................33

C. Analisis Perbandingan Teori Dengan Realita Atas Prosedur yang Terkait

D. Analisis perbandingan Teori Dengan Realita atas Catatan yang digunakan

E. Hasil Analisis PIECES Dengan Situasi Pada CV. Tetap Jaya Medan Petisah 35

F. Hasil analisis sistem pengendalian internal dengan situasi pada CV. Tetap Jaya .38

BAB VI KESIMPULAN

DAFTAR PUSTAKA 


\section{BAB I \\ PENTINGNYA TEKNOLOGI INFORMASI \\ DALAM PERUSAHAAN}

\section{A. Sistem Informasi dalam Operasional dan Manajerial Perusahaan}

Teknologi informasi merupakan bagian yang penting dan berharga dalam kegiatan bisnis pada era globalisasi seperti sekarang ini. Informasi yang akurat dan tepat waktu akan membantu manajer dalam mengambil keputusan dan menentukan langkah-langkah yang harus dilakukan untuk mempertahankan dan mengembangkan organisasi serta usahanya. Informasi juga mendukung kegiatan operasional dan manajerial organisasi. Dan untuk semua itu dibutuhkan suatu pengolahan data yang handal, akurat, dan dapat ditampilkan secara tepat dan mudah apabila setiap kali diperlukan.

Ketatnya suatu persaingan pasar, mengharuskan sebuah usaha untuk memiliki pelayanan yang baik serta memiliki informasi yang akurat dan tepat waktu. Informasi tersebut dapat membantu suatu bisnis dalam melakukan pengambilan keputusan yang berkaitan dengan operasi dan perkembangan usaha. Kebutuhan mengenai informasi yang akurat dan tepat waktu sangat penting untuk dimiliki suatu usaha, terutama pada lingkup usaha dagang. Definisi mengenai sistem informasi yaitu Stair dan Reynolds (2010), mengatakan bahwa yang dimaksud dengan informasi merupakan kumpulan fakta yang sudah terorganisir sedemikian rupa, sehingga pada akhir memiliki nilai tambah pada usernya, selain fakta individu itu sendiri. Selain itu, 
Bodnar \& Hopwood (2013), mengatakan bahwa yang dimaksud dengan sistem informasi akuntansi merupakan suatu kumpulan dari berbagai macam sumber daya, seperti manusia dan juga peralatan yang dirancang untuk mengubah data keuangan dan juga data lainnya menjadi sebuah informasi yang berguna bagi user dan penggunanya. Dalam pengoperasiannya, aktivitas pada suatu usaha dagang terdiri dari membeli dan menjual produk, bukan jasa. Usaha dagang (merchandising businesses) menjual produk yang diperoleh dari pihak lain ke pelanggan. Penjualan produk dalam kegiatan bisnis suatu usaha dagang dilakukan tanpa melalui proses produksi. Pendapatan pokok yang diperoleh dari usaha dagang berasal dari transaksi penjualan barang dagang. Hal ini menunjukkan bahwa suatu usaha dagang memiliki tujuan untuk mendapatkan laba yang besar dalam jumlah penjualan dan keuntungan bagi perusahaan.

CV. Tetap Jaya merupakan salah satu usaha yang bergerak dibidang usaha dagang yang menyediakan berbagai jenis bahan-bahan kue dan peralatan kue serta berbagai hiasan aksesoris kue. CV. Tetap Jaya beralamatkan di Jalan Rotan no.55, Medan Petisah, Sumatra Utara. CV. Tetap Jaya merupakan usaha dagang yang cukup besar dan menyerupai supermarket yang menjual produknya secara grosir serta miliki banyak pelanggan mulai dari daerah setempat dan bahkan dari luar kota juga. Dan harga yang ditawar kan oleh CV. Tetap Jaya cukup terjangkau sehingga toko tidak pernah sepi pelanggan, sistem yang dilakukan oleh CV. Tetap Jaya masih menggunakan sistem manual dan juga menggunakan software kasir point of sale namun pada saat 
pembayaran banyak pelanggan yang harus mengantre disebabkan oleh perangkapan tugas. menurut Wiratna Sujarweni (2015:79), menyatakan bahwa sistem penjualan tunai merupakan sistem yang dijalankan perusahaan dalam menjual barang dengan cara mewajibkan pembeli untuk melakukan pembayaran harga terlebih dahulu sebelum barang diserahkan kepada pembeli.

Sistem pencatatan transaksi penjualan yang diterapkan pada CV. Tetap Jaya masih ada juga menggunakan manual menggunakan nota rangkap sehingga kinerjanya belum efektif dan pemilik perusahaan sulit untuk memperoleh informasi yang dibutuhkan dalam waktu yang cepat dan akurat. Tidak ada pencatatan Laporan persediaan harian pada CV. Tetap Jaya hal ini mempersulit pemilik untuk memperoleh informasi persediaan setiap harinya. Selain itu, pengendalian internal pada CV. Tetap Jaya masih kurang baik, karena pada toko tersebut belum ada pemisahan tugas antar karyawannya, karyawan yang bertugas menjadi kasir juga bertugas untuk mengecek barang di bagian display.

Selain itu , karyawan juga merasa kesulitan dalam melakukan pengelolaan persediaan barang pada toko $\mathrm{CV}$. Tetap jaya sehingga menyebabkan karyawan harus mengecek barang digudang apa bila barang di display kosong. Pengelolahan persediaan yang kurang baik tersebut dapat menimbulkan suatu permasalahan yang menyebabkan terjadinya kekosongan barang dagangan yang akan berimbas pada penjualan tunai toko CV. Tetap Jaya. Oleh karena itu CV. Tetap jaya membutuhkan sistem informasi penjualan tunai terkomputerisasi. Dengan demikian CV. Tetap jaya diharapkan mampu 
meningkatkan efesiensi dan efektivitas kegiatan operasional dengan adannya sistem informasi akuntansi penjualan tunai terkomputerisasi.

Berdasarkan latar belakang di atas, maka penulis akan melakukan analisis terhadap sistem informasi akuntansi penjualan tunai pada CV. Tetap Jaya. Kajian yang digagas dalam buku ini berdasarkan referensi dari penelitian terdahulu yaitu Dewi Indriyani Fur Koni (2019), “Analisis Perancangan Sistem Informasi Penjualan Tunai Jasa Service Berbasis Database Dalam Upaya Meningkatkan Kualitas Informasi Studi kasus pada CV Imprasium Tehnik" sementara kajian yang penulis lakukan tentang Analisis Sistem Informasi Akuntansi Penjualan Tunai Terkomputerisasi Studi kasus Pada CV. Tetap Jaya; serta perbedaannya terletak pada penelitian ini membuat rancangan sistem informasi akuntansi penjualan yang lebih terkomputerisasi menggunakan Database Management System sedangkan penulis menggunakan software kasir point of sale (POS) serta mengunakan Analisis PIECES.

\section{B. Metodologi Kajian}

Jenis penelitian yang digunakan dalam kajian di buku ini adalah metode deskriptif kualitatif dengan pendekatan studi kasus. Penelitian Kualitatif yaitu sebagai kegiatan yang meliputi pengumpulan data dalam rangka menjawab pertanyaan yang menyangkut keadaan waktu sedang berjalan dari pokok suatu penelitian. Penelitian deskriptif ini bertujuan untuk mendeskripsikan atau menjelaskan suatu hal seperti apa adanya, sehingga memberikan gambaran yang jelas tentang situasi-situasi di lapangan apa adanya. 
Dengan menggunakan penelitian deskriptif kualitatif akan diupayakan untuk mencari pemahaman tentang kenyataan dari segi perspektif dari orang yang memang ahli dibidangnya. Dalam proses penelitian data yang diperoleh tidak ada yang salah karena data akan dianggap benar semua. Burhan Bungin dalam Purhantara (2010:59). Kualitatif karena data diperoleh dari hasil observasi langsung dan melalui wawancara kepada pemilik CV. Tetap Jaya.

Penjualan tunai merupakan transaksi penjualan yang mengharuskan pembeli membayar harga barang yang diinginkan pembeli terlebih dahulu. Setelah pembeli melakukan pembayaran, maka barang tersebut diserahkan kepada pembeli. Lalu perusahaan melakukan pencatatan transaksi penjualan tunai pada buku catatan penjualan.

Sistem informasi akuntansi penjualan tunai terkomputerisasi merupakan proses pengolahan data transaksi penjualan tunai dengan memanfaatkan teknologi informasi berupa komputer sehingga menghasilkan informasi yang dapat digunakan oleh pihak manajemen untuk membuat laporan keuangan.

Perancangan sistem informasi akuntansi penjualan tunai terkomputerisasi adalah pengembangan sistem untuk memperbaiki sistem pengolahan data yang berkaitan dengan penjualan tunai pada perusahaan dengan memanfaatkan teknologi informasi yaitu komputer. Tahapan penelitian dilakukan secara berkesinambungan yang dimulai dengan tahapan penyusunan gagasan, proses pengembangan hingga implementasi guna memproses data penjualan tunai 
sebagai input dan menghasilkan laporan keuangan yang berguna untuk manajemen dalam pengambilan keputusan.

Subjek dalam kajian ini adalah pemilik beserta karyawan CV Tetap Jaya, sedangkan Objeknya adalah semua yang berkaitan dengan sistem informasi akuntansi penjualan tunai yang diterapkan oleh CV. Tetap Jaya.

Sumber data di dalam penelitian merupakan faktor yang sangat penting, karena sumber data akan menyangkut kualitas dari hasil penelitian. Oleh karenanya, sumber data menjadi bahan pertimbangan dalam penentuan metode pengumpulan data. Sumber data terdiri dari sumber data primer dan sumber data sekunder. (Purhantara, 2010:79).

Data Primer adalah data yang dikumpulkan langsung oleh peneliti dari percobaan atau kegiatan lapangan yang dilakukan. Data ini merupakan data asli atau orisinal yang baru pertama kali diperoleh. Data ini sangat bermanfaat bagi penelitian yang sedang dilakukan dan juga untuk penelitian di masa depan sebagai data sekunder (Timotius, 2017:69).

Pada kajian ini jawaban data primer diperoleh dari hasil observasi langsung dan wawancara dengan pemilik dan karyawan CV. Tetap Jaya. Dalam data ini pula peneliti melakukan observasi langsung mengenai struktur organisasi, aktivitas operasional yang terjadi, dan gambaran umum organisasi.

Data sekunder merupakan data yang sifatnya mendukung keperluan data primer. Data Sekunder umumnya berupa bukti, catatan atau laporan historis 
yang telah tersusun dalam arsip (data dokumenter) yang dipublikasikan dan yang tidak dipublikasikan. Dalam penelitian ini, data sekunder didapat dari buku dan jurnal penelitian terdahulu.

Observasi adalah teknik pengumpulan data dengan cara melakukan pengamatan langsung terhadap objek yang diteliti. Dalam hal ini penulis melakukan observasi langsung pada CV. Tetap Jaya yang terletak di jalan rotan no.55 medan petisah dengan mengamati kegiatan operasional penjualan bahan-bahan kue, pembelian bahan-bahan kue dan pelayan terhadap konsumen serta transaksi dan pencatatan laporan keuangan. Observasi dilakukan pada saat jam kerja perusahaan yang dimulai dari jam 8.30-18.00 WIB.

Wawancara dilakukan sebelum penulis melakukan analisis sistem informasi akuntansi. Teknik wawancara ini dilakukan bertujuan untuk mengetahui gambaran umum perusahaan, sistem informasi akuntansi yang telah diterapkan oleh CV. Tetap Jaya, dan melakukan wawancara terhadap pihak-pihak yang terkait dengan penelitian ini, seperti kepada Direktur CV. Tetap Jaya yaitu ibu Lili Gozali dan bagian administrasi yaitu bapak Erwin Kartolo pertanyaan wawancara didapat dari analisis dokumen dan pertanyaan juga bersifat fleksibel sesuai dengan alur pembicaraan. Data yang didapatkan kemudian dianalisis sesuai dengan teknik analisis data.

Studi Kepustakaan merupakan pendukung penelitian yang berasal dari pandangan-pandangan ahli dalam bentuk yang tertulis berupa referensi buku, jurnal, laporan penelitian atau karya ilmiah lainnya (Satori dan Komariah, 2011:105). Dalam hal ini penulis menggunakan 
buku-buku, jurnal maupun literatur-literatur terkait mengenai studi Sistem Informasi Akuntansi Penjualan

Untuk menguji keabsahan data diperlukan teknik pemeriksaan data didasarkan atas sejumlah kriteria tertentu. Ada 4 (empat) kriteria yang dapat digunakan dalam penelitian kualitatif (Bachri, 2010:55), yaitu Credibility, Transferability, Dependability, Confirmability. Agar data dalam penelitian kualitatif dapat dipertanggungjawabkan, perlu dilakukan uji keabsahan data.

Teknik analisis data adalah suatu teknik yang digunakan sebagai alat bantu bagi peneliti untuk mengambil suatu keputusan atas jumlah data penelitian yang telah terkumpul (Sugiyono, 2013:239). Analisis data dalam kajian ini dilakukan secara kualitatif yaitu suatu analisis yang berusaha mencari pola, model, tema, hubungan, persamaan dan makna dari data yang dinyatakan dalam bentuk pernyataan-pernyataan, tafsiran-tafsiran setelah menggali data dari beberapa orang informan kunci yang ditabulasikan dan dipresentasikan sesuai dengan hasil temuan (observasi) dan wawancara mendalam penulis dengan para informan. 


\section{BAB II \\ SISTEM INFORMASI AKUNTANSI}

\section{A. Definisi Sistem}

Menurut Nugroho (2017:35) Sistem adalah kumpulan dari berbagai parameter yang menuju keteraturan untuk memenuhi tujuan yang telah disepakati dalam suatu organisasi atau kelompok yang satu visi dan satu misi.

Berbeda dengan Mulyadi (2016:2) yang berpendapat bahwa Suatu sistem pada dasarnya adalah sekelompok unsur yang erat berhubungan satu dengan yang lainnya, yang berfungsi bersama-sama untuk mencapai tujuan tertentu. Sedangkan menurut Romney dan Steinbart (2015:3) Sistem adalah suatu rangkaian yang terdiri dari dua atau lebih komponen yang saling berhubungan dan saling berinteraksi satu sama lain untuk mencapai tujuan dimana sistem biasanya terbagi dalam sub sistem yang lebih kecil yang mendukung sistem yang lebih besar.

Berdasarkan definisi di atas maka dapat disimpulkan bahwa sistem adalah sekumpulan unsur yang saling berhubungan satu dengan yang lainnya dalam suatu kelompok dalam rangka mencapai satu tujuan bersama.

\section{B. Karakteristik sistem}

Sebuah sistem mempunyai karakteristik atau sifatsifat tertentu yaitu mempunyai komponen-komponen, batasan sistem, lingkungan luar sistem, penghubung, masukan, keluaran, pengolah, dan sasaran. Adapun karakteristik yang dimaksudkan adalah : 
1. Komponen Sistem (component)

Suatu sistem yang terdiri dari sejumlah komponen yang saling berinteraksi, yang artinya saling bekerja sama membentuk satu kesatuan.

2. Batasan Sistem (boundary)

Batasan sistem merupakan daerah yang membatasi antara suatu sistem dengan sistem yang lain. Batasan sistem ini memungkinkan suatu sistem dipandang sebagai satu kesatuan. Batasan sistem menunjukkan ruang lingkup dari sistem tersebut.

3. Lingkungan luar sistem (environments)

Lingkungan luar sistem adalah apapun diluar batas dari sistem yang mempengaruhi operasi sistem. Lingkungan luar dapat bersifat menguntungkan dan juga merugikan sistem tersebut.

4. Penghubung (interface)

Penghubung sistem merupakan media penghubung antara satu sub sistem yang lainnya. Melalui penghubung ini memungkinkan sumber daya mengalir dari satu subsistem ke subsistem lainnya.

5. Masukan (input)

Masukan sistem adalah energi yang dimasukkan ke dalam sistem. Masukan dapat berupa masukan perawatan (maintenance input) dan masukan sinyal (signal input). Maintenance input adalah energy yang dimasukkan supaya sistem tersebut dapat beroperasi. Signal Input adalah energy yang diproses untuk didapatkan keluaran 
6. Keluaran (output)

Keluaran sistem adalah hasil dari energy yang diolah dan diklasifikasikan menjadi keluaran yang berguna dan sisa pembuangan. Keluaran dapat merupakan masukan untuk sub sistem yang lain atau kepada suprasistem.

7. Pengolah (processing)

Suatu sistem dapat mempunyai suatu bagian pengolah yang akan merubah masukan menjadi keluaran.

8. Sasaran (objectivities)

Merupakan tujuan yang akan dicapai untuk menentukan masukan yang dibutuhkan sistem dari keluaran yang akan dihasilkan sistem.

\section{Klasifikasi sistem}

Sistem dapat diklasifikasihkan dari beberapa sudut pandang, diantaranya sebagai berikut:

1. Sistem abstrak dan fisik

Sistem abstrak adalah sistem yang berupa pemikiran atau ide-ide yang tidak tampak secara fisik.

2. Sistem alamiah dan sistem buatan manusia.

Sistem alamiah adalah sistem yang terjadi melalui proses alam, tidak dibuat manusia. Sistem terbuka adalah sistem yang berhubungan dan terpengaruh dengan lingkungan luarnya.

3. Sistem tertentu dan sistem tak tentu

Sistem tertentu beroperasi dengan tingkah laku yang sudah dapat diprediksi. Sistem tak tentu adalah 
sistem yang kondisi masa depannya tidak dapat diprediksi karena mengandung unsur probabilitas.

4. Sistem tertutup dan sistem terbuka

Sistem tertutup adalah sistem yang tidak berhubungan dan tidak terpengaruh dengan lingkungan luarnya. Sistem terbuka adalah sistem yang berhubungan dan terpengaruh dengan lingkungan luarnya.

5. Informasi atau laporan-laporan

Sistem informasi menghasilkan informasi yang bermanfaat bagi penggunaan internal maupun eksternal dalam mengambil keputusan. Informasi dapat berbentuk hasil cetak komputer maupun tampilan monitor.

\section{Definisi informasi}

Menurut Nugroho (2017:9) Sistem adalah sekumpulan fakta-fakta yang telah diolah menjadi bentuk data, sehingga dapat menjadi lebih berguna dan dapat digunakan oleh siapa saja yang membutuhkan data-data tersebut sebagai pengetahuan ataupun dapat digunakan dalam pengambilan keputusan. Berbeda dengan Daud dan Windana (2014:18) yang menyatakan bahwa Informasi merupakan data yang diproses sehingga mempunyai arti tertentu bagi penerimanya.

Sedangkan menurut Romney dan Steinbart (2016:4) Informasi adalah data yang telah dikelola dan diproses untuk memberikan arti dan memperbaiki proses pengambilan keputusan. Berdasarkan beberapa definisi informasi diatas maka dapat disimpulkan bahwa informasi adalah sebuah data yang telah melalui proses 
yang memiliki suatu arti dalam memberikan sebuah keputusan bagi penerimanya.

\section{E. Definisi sistem informasi}

Menurut Nugroho (2017:56) Sistem informasi merupakan suatu perangkat kerja yang dapat bekerja untuk memproses suatu masukan ataupun data, kemudian data yang telah diproses tersebut akan diproses dan menjadi suatu keluaran yang berguna untuk mencapai suatu tujuan tertentu.

Berbeda dengan Sutarman (2012:13) yang menyebutkan bahwa Sistem informasi adalah sistem yang dapat didefinisikan dengan mengumpulkan, memproses, menyimpan, menganalisis, menyebarkan informasi untuk tujuan tertentu.

Sedangkan menurut Sutabri (2012:46) Sistem informasi adalah suatu sistem di dalam suatu organisasi yang mempertemukan kebutuhan pengolahan transaksi harian yang mendukung fungsi operasi organisasi yang bersifat manajerial dengan kegiatan strategi dari suatu organisasi untuk dapat menyediakan kepada pihak luar tertentu dengan laporan-laporan yang diperlukan.

Berdasarkan beberapa definisi di atas maka dapat disimpulkan bahwa sistem informasi adalah suatu sistem yang bekerja dengan memproses masukan (input) kemudian diolah melalui serangkaian proses menjadi sebuah keluaran data (output) yang digunakan untuk suatu tujuan tertentu dalam organisasi. 